Asia Pacific fournal of Education

Vol. 27, No. 1, March 2007, pp. 55-71

Routledge

8. Trylor \& Francis Croup

\title{
Muslim Schools in Britain: Challenging mobilisations or logical developments?
}

\author{
Nasar Meer` \\ Department of Sociology and Centre for the Study of Ethnicity and Citizenship, University of \\ Bristol, UK
}

\begin{abstract}
There are currently over 100 independent and seven state-funded Muslim schools in Britain yet their place within the British education system remains a hotly debated issue. This article argues that Muslim mobilisations for the institutional and financial incorporation of more Muslim schools into the national framework are best understood as an addition to - or continuation of - a historical settlement between earlier religious minorities, the established church, and the state. To this end the article begins by assessing the relationship between governmental policy and the nature of Muslim identities that are presently informing Muslim mobilisations. It then addresses the arguments against Muslim schooling found in some of the broader philosophical, political, and sociological literature. Particular attention is afforded to the issue of autonomy, the role of civic assimilation in the remaking of British-Muslim constituencies as well as Muslim curriculum objectives and their implications for social cohesion. The article concludes that Muslim schools can herald a constructive addition to the educational landscape and serve as an effective method of integrating religious minorities into a matrix of British citizenship.
\end{abstract}

\section{Introduction}

The position of Muslim schools within the British education system remains a hotly debated issue, with advocates and opponents each eliciting emotive charge and counter-charge. In a highly publicised speech, for example, David Bell (2005), Chief Inspector of Schools and head of the Office for Standards in Education, warned that separate Muslim schools "do not fit pupils for their lives as Muslims in modern Britain" (Understanding national identity, para. 12), and that the schools themselves:

must adapt their curriculum to ensure that it provides pupils with a broad general knowledge of public institutions and services in England and helps them to acquire an appreciation of and respect for other cultures in a way that promotes tolerance and harmony. (Understanding national identity, para. 11)

\footnotetext{
^Dept. of Sociology and Centre for the Study of Ethnicity and Citizenship, 12 Woodland Road, Bristol, BS8 2TY. Email: Nasar.Meer@bristol.ac.uk

ISSN 0218-8791 (print)/ISSN 1742-6855 (online)/07/010055-17

(C) National Institute of Education, Singapore (2007)

DOI: $10.1080 / 02188790601145374$
} 
Proponents of Muslim schooling immediately rejected the idea that these schools were not already meeting these requirements. Dr Mohamed Mukadam (2005), Chair of the Association of Muslim Schools (AMS), accused Bell of "Islamophobia" before challenging him to a public debate. The reason why the AMS felt that Muslim schools were being treated unfairly was partly due to findings that 18 of the 50 Muslim schools inspected by Mr Bell's organisation in the previous year were cited for failing to teach "tolerance" while 17 of the 40 evangelical Christian schools inspected-a comparatively higher proportion-received equally poor marks in the same area (Office for Standards in Education [OFSTED], 2004). Mukadam argued that because Bell failed to acknowledge this or that the vast majority of Muslim schools had already passed compulsory inspections, with those at issue constituting a very small proportion, either the inspections had been imprecise or the comments too sweeping.

There has in fact emerged a series of generic objections, particularly since the London bombings on 7 July 2005, concerning the compatibility of Muslim Schools with life in Britain. ${ }^{1}$ In an effort to negate the cycle of emotive charge and countercharge, this article examines key aspects of the debate surrounding both the 115 independent and seven state-funded Muslim schools in Britain. The first section of the article examines the relationship between governmental policy and expressions of identity that are presently informing Muslim mobilisations. It then locates these mobilisations within the historically peculiar British schooling context that, it is argued, provides a means of understanding their emergence as a logical development. The second section of this article discusses some of the broader philosophical, political, and sociological literature in addressing the arguments against Muslim schools. Particular attention is afforded to the issue of autonomy, the role of civic assimilation in the remaking of British-Muslim constituencies, as well as Muslim curriculum objectives and issues of social cohesion.

\section{The Policy Context}

The aforementioned comments by David Bell (2005) were not made in a political vacuum. A series of debates over schools with a Muslim ethos had already been in circulation since 1998 when, after 18 years of a Conservative administration, Tony Blair's newly elected Labour government delivered on a promise made in its election manifesto and awarded two Muslim primary schools (Islamia in London and AlFurqan in Birmingham) voluntary aided (VA) status. It arrived "fourteen years and five Secretaries of State after the first naïve approach" (Hewitt, 1998, p. 22) when Muslim parents and educators were only beginning to come to grips with the convoluted application practices and a hostile Conservative government. This move conferred an allocation of public money upon schools to cover teacher salaries and the running costs of the school.

Both Islamia and Al-Furqan had already undergone a strict inspection by OFSTED and had more than met the appropriate governmental criteria for independent schools 
applying for state funding. Aside from obvious requirements such as the delivery of a good standard of education and the economic feasibility of the school, the Department for Education and Skills (2004) included the following criteria:

1. adoption and delivery of the National Curriculum (ranging from a "thinner" to "thicker" version depending on whether the school is VA or voluntary controlled as discussed below);

2. appointment of appropriately qualified staff;

3. suitable school buildings;

4. equality of opportunity for both male and female pupils; and

5. consideration of parental demand.

All of this, of course, is premised upon the "need" for a school in a given area based upon the number of available pupil spaces. In the past, the availability of school places (and therefore the lack of a "need") has been cited as the principle reason for-having met all other criteria-refusing some Muslim schools to opt into the state system while simultaneously inviting other religious schools in similar areas to do so (see Association of Muslim Social Scientists [AMSS], 2004, p. 20 and Parker-Jenkins, 2002, p. 279).

Nevertheless, the success of these two schools was given further impetus in the Government Green Paper, Schools: Building on Success (Department for Education and Employment, 2001), so that nine years and another three Secretaries of State later, the current number of state-funded Muslim faith schools had risen to seven. This includes Al-Hijrah (a secondary school in Birmingham), Feversham College (a secondary school in Bradford), Gatton Primary School (Wandsworth, South London), Tauheedul Islam Girls High School (Blackburn, Lancashire), and The Avenue School (another primary school in Brent, London).

Compared to the 4,700 state-funded Church of England schools, 2,100 Catholic schools, 37 Jewish and 28 Methodist schools, Muslim campaigns for equal opportunity in the faith schooling of Muslim children in the state sector is indicative of "a modern society which is widely perceived as increasingly secular but is paradoxically increasingly multi-faith" (Skinner, 2002, p. 172). If we consider how successfully the Swann Report (Swann, 1985), the very influential public policy document in British education, had moved the mainstream agenda away from faith schooling in the state sector as a realistic educational option for minority ethnic children, this "paradox" is particularly interesting. Fearing that faith schooling for minority students would stifle educational progress, the Swann Report concluded that "the establishment of 'separate' schools could well fail to tackle many of the underlying concerns of the communities and might also exacerbate the very feelings of rejection and not being accepted" (Swann, 1985, p. 509).

These "underlying concerns" are discussed in the next section of this article but it is worth noting that these include the complaint by Muslim parents and educators that they are afforded an impaired citizenship in not being extended the same ratio of 
provisions available to other major faith groups (AMSS, 2004; Anwar \& Bakhsh, 2003; Ameli et al. 2005). This is particularly evident as we review the current situation, with the Church of England overseeing just over a quarter of all state schools and the near impossibility of it being de-coupled from the Established Church (neither desired nor proposed by advocates of Muslim faith schooling) (cf. Modood, 1997).

\section{Key Numerical Data and Identity Implications}

This issue becomes more pressing as we examine some key statistics on Muslim children of school age because, numerically, they are disproportionately present in the British education system. Comprising nearly $6 \%(500,000)$ of the school population from the entire Muslim population of 3\% (1.8 million) (Halstead, 2005, p. 104; Office for National Statistics [ONS], 2005), there is a striking contrast between the number of Muslim children and the number of Jewish children of school age $(50,000)$-who represent $0.4 \%$ of the school population. Reflecting the particularly youthful national demographic of British-Muslims, where $33.8 \%$ are $0-15$ years old and $18.2 \%$ are $16-24$ years old (Scott, Pearce, \& Goldblatt, 2001), in some local education authorities (LEAs) this translates into a significant Muslim presence amongst school districts and wards. This is partially the result of concentrated settlement patterns by first-generation migrant workers (often intensified by the "white flight" to the suburbs, cf. Ratcliffe, 1996) which, in cities such as Bradford, means that roughly $33 \%$ of total school population is of predominantly Muslim ethnic minority origin (OFSTED/Audit Commission, 2002). As a result, "a significant number of inner city schools in Bradford almost exclusively serve the Muslim population" (Halstead, 2005, p. 110)—a pattern not uncommon in other cities home to significant post-war minority ethnic settlement (see ONS, 2005).

It is important to note that Muslim pupils come from diverse ethnic backgrounds which, alongside the Pakistani (40\%) and Bangladeshi (20\%) contingent, include the Turkish, Turkish-Cypriot, Middle Eastern, East Asian, and African-Caribbean (which amount to 10\%); Indian or other South Asians (15\%); those of mixed race or heritage $(4 \%)$; and a not insignificant number of White converts and Eastern Europeans (1\%) (Burgess \& Wilson, 2004). This diversity does not, however, punctuate or unravel the unity of a transcending Muslim identity but moves us much closer to a type of "strategic essentialism" (Spivak, 1988) which is advocated in their different ways by the anthropologist Pnina Werbner (1997) and sociologist Tariq Modood (2005). The pedagogical variant of this means that although they are "multicultural, multi-racial and multi-lingual in nature, it is the faith dimension of their lives which provides the unifying character" (Parker-Jenkins, 1995, p. 93). This is important for the following reasons. Firstly, from an educational perspective, it requires us to recognise that during their early socialisation, "most Muslim children will, through family and community activities ... if not more through more formal religious observance, come into contact with the religion of Islam on a regular basis" (Halstead, 2005, p. 111). In doing so, it begins to absorb much of the tension in the problematic distinction between "practising" and "non-practising" Muslims- 
specifically by viewing the former as a matter of degree and definition (given that there are many ways Islam can be practised). Secondly, it emphasises that much of the motivation for Muslim faith schools in Britain actually rests on the desire of Muslim parents to embrace faith schooling as an avenue to instil some sense of a Muslim heritage in all its heterogeneity. ${ }^{2}$ This was the finding of Patricia Kelly who, in her ethnographic study of schooling choices made by Muslim parents with both secular and Islamic worldviews in Canada and Britain, argued that:

As some less-religious families do opt for specifically Muslim education, we can consider this as an example of a decision selectively to emphasise this pan-ethnic (Muslim) group identity, in order to reap whatever benefits-economic, social and psychological as well as spiritual-it offers. (1999, p. 203)

This rationale permeates the Association of Muslim Social Scientists' manifesto, Muslims on Education, in which the term "Muslim" refers "not only [to] practising adherents of Islam, but also those who identify themselves as such (without necessarily being practising Muslims) or belong to a household or family that holds Islam as its descendant faith" (2004, p. 11). This conception of Muslim identity is expressed and consolidated in survey data that inevitably include both practising and non-practising Muslims. Yet, it reports that $74 \%$ of a representative adult Muslim sample in Britain consider religion "very important" (Modood \& Bertroud, 1997, p. 331) without necessitating an inquiry into their degree of religiosity, let alone what this might entail behaviourally.

\section{Muslim Motivations for Faith Schools}

Bearing in mind the different ways of being Muslim, there are a number of factors that coalesce to inform the broad interest in Muslim schooling. Firstly, there is the desire to incorporate more faith-based principles into an integrated education system, so that the "whole person" can be educated in an Islamic environment (AMSS, 2004; Haque, 2002; Hewer, 2001). This would presuppose faith rather than treating it as something extraneous to education and external to its major objects (Ashraf, 1990). For example, one recommendation that emerged from the First World Conference on Muslim Education states that, "education should aim at the balanced growth of the total personality through the training of spirit, intellect, the rational self, feelings and bodily senses" (cited in AMSS, 2004, p. 12). Two approaches favoured by the AMSS are the Steiner and Montessori approaches, both of which encourage personal and team responsibility while "the child's creativity is also given full freedom for expression" (cited in AMSS, 2004, p. 19).

Secondly, and based upon an interpretation of Islam which posits that "after puberty boys and girls should be separated" (Hashmi, 2002, p. 14), there is a concern about the development of "safe" environments for post-pubescent children. In this regard, single-sex schooling appeals to Muslim parents (Halstead, 1992, 1997; Hewer, 2001). In Bradford, for example, the Muslim Parents Association was formed in 1974 on this 
single issue, supporting the creation of a number of independent single-sex Muslim schools with separate teaching rooms (cf. Haw, 1998). The creation of Feversham College exemplifies this approach, which is paralleled in some Catholic faith schooling (Halstead, 1991). However, this is not a desired policy for primary schooling and is contradicted by some existing co-educational (male and female) Muslim schools that employ mixed teaching classes. The retention of single-sex schooling was recommended by the Swann Committee (Swann, 1985) and its non-availability may also influence Muslim parents' interest in faith schooling. Simultaneously, this should not be dismissed as patriarchal given the strong pedagogical arguments advocating the role of single-sex schools in "emancipating" girls (Keaton, 1999).

The third factor influencing the broad interest in Muslim schooling is the aspiration for establishments that offer "specialist training in the Islamic religious sciences" in conjunction with general education so that young people might "be educated to serve their community as potential religious leaders" (Hewer, 2001, p. 518). This includes the desire to have more British-trained theologians who can discuss theological issues with a contemporary resonance to the lived experiences of being Muslim in Britain.

Fourthly, and in order to impart more accurate knowledge of Islamic civilisations, literature, languages, and arts (both past and present), Muslims also want to see more aspects of Islamic culture embedded within the teaching and ethos of school curricula normatively couched within a Christian-European tradition. In their study of school textbooks, for example, Douglass and Shaikh (2004) found that Islam is rarely portrayed in the way it is understood by its adherents. Rather, it is often described based on the ethnocentric perspectives of editors who frame their commentary for textbook adoption committees. Common examples include the portrayal of the Prophet Muhammad as the "inventor" of Islam rather than a messenger or prophet and the artificial separation of Islam from other monotheistic faiths. This feeds into the broader charge that LEAs have only "tinkered with the largely ethnocentric curricula, leaving Muslim children feeling alienated and with damaged self-esteem" (Ansari, 2002, p. 22).

Finally, there is a concern over the lower educational attainment of some Muslim boys and the belief that greater accommodation of religious and cultural difference will help resolve this low achievement. For example, in 2000, only $30 \%$ of boys with Pakistani and Bangladeshi ethnic origin achieved five GCSEs ${ }^{3}$ at grades $A \star-C$ as compared to $50 \%$ of the national population as a whole (for a much fuller statistical summary see Halstead, 2005). This could indicate "the sense of alienation and disaffection felt by many young male Muslims at school" (Halstead, 2005, p. 136). This is an assertion given empirical support in a study undertaken by the IQRA Trust (see Pye, Lee, \& Bhabra, 2000) and was raised by the Commission on the Future of Multi-Ethnic Britain (CMEB). The CMEB recommended governmental targets to decrease the number of school exclusions currently experienced by some Muslim groups (2000, p. 152). While it is accepted that parental education and social class play an important role in shaping these educational outcomes, Halstead lists other relevant issues including "religious discrimination; Islamophobia; the lack of Muslim role models in schools; low expectations on the part of teachers; time spent in 
[extra-curricular] mosque schools; the lack of recognition of the British Muslim identity of the student" (2005, p. 137). Such a list helps explain why some feel that Muslim schools could help counter these experiences and elevate educational outcomes. This is seen in the academic achievements of Muslim schools. All GCSE entrants from Al-Furqan Community College (Birmingham), Leicester Islamic Academy, Madani School (Tower Hamlets), Tayyibah School (Hackney), and Brondesbury College (Brent) have achieved five or more passes at grades $A \star-C$, with Feversham College achieving 53\% of such passes - higher than the national average (and well above the Bradford average). At the same time, the Islamia School came first (or third depending on the measure used) in a district of 51 schools examined at the Key Stage Two level (Halstead, 2005, p. 137). ${ }^{4}$

Where Muslim parents have opted out of the state sector, the desire for more holistic schooling has resulted in the creation of over 100 independent schools with a Muslim ethos, educating over 14,000 pupils from ethnically diverse communities in predominantly inner city areas. These institutions deliver both "secular" and Islamic education and are best described as Muslim schools with "the goal of living up to the standards of Islam, rather than implying its achievement" (Douglass \& Shaikh, 2004, p. 8). Typically established "in homes, mosques and similar buildings by a group of concerned parents and community leaders" (Hewer, 2001, p. 518), the vast majority are comprised of low-fee schools in poor-quality buildings. Unsurprisingly, they lack many of the basic facilities common to state schools (Walford, 2003). The main reason for this is financial insecurity. At the same time, Muslim schools rely on community support and are seldom purpose built. As a result, they open and close depending on the resources and stability afforded by the local Muslim communities. Thus, despite being private institutions, Muslim schools may be better thought of as "community-based schools" due to the fact that they rarely operate commercially and more often than not, rely upon the aforementioned community support-in particular, the "sacrificial efforts of teachers and school administrators" (Hewer, 2001, p. 518).

\section{Government Funding and "Voluntary Aided" Schooling}

Many existing Muslim schools therefore seek to be co-opted into the state sector under the status of a voluntary aided (VA) school. The notion of a VA school has its roots in the organic creation of a "dual system" (O'Keefe, 1986), organised in terms of parallel but interacting state and faith-based schooling. This results from the "contributions of parish clerics to village teaching, church foundation grammar schools" of the 18th and 19 th centuries which established churches as almost "exclusive providers in the early stages of progress towards universal education" (Skinner, 2002, p. 173). On the other hand, not withstanding the Victorians' hesitancy to get involved in "what had, hitherto, been a purely private concern", the social and economic upheaval of the Industrial Revolution led to the realisation that education was "an important agent of social reform to assist the nation in its economic endeavours" (Parker-Jenkins, 2002, p. 275). This culminated in the creation of a statutory system of public education with the 1870 Elementary Education Act. As Skinner (2002) notes, however, this failed to satisfy 
competing Christian bodies in their views about education, the practice of providing schooling, and the money with which to do so:

The established church of England was not the only powerful Christian denomination in Britain. In Scotland, the majority of Scottish people were not Anglican but Presbyterians. Protestant nonconformists were strong in Wales and England. The increase in early 18th century migration from Ireland meant that Roman Catholic presence was also increasing. These groups stood out against the state for giving every opportunity to the Church of England to proselytise through the education system. (p. 174)

In general terms, the introduction of the 1944 Education Act sought to reach a compromise between the historic contribution of faith groups and their internal differences with the increasing role of the state in education. This was pursued by awarding independent faith schools the option (subject to meeting the appropriate standards and criteria) of becoming voluntary aided (VA) or voluntary controlled (VC). The former status allowed the provision of denominational religious instruction and acts of worship alongside the right to appoint teachers based on the understanding that the school shoulders half the cost of any structural or building improvements. In addition, the majority of school administrators could be drawn from the diocesan board of education or religious authority. The latter, meanwhile, incurred no financial responsibilities but did not have any denominational worship. At the same time, the majority of VC schools' administrators were appointed by the LEA.

Most important to this discussion is that although it was not anticipated that "other religious groups would one day like to take advantage of the provisions" (Hewer, 2001, p. 518), the relevant clauses of the 1944 Act do not specify which denominational groups are to be included in the scheme. However, Muslims have found themselves in a discouraging position in relation to this provision. As Hewer describes:

new schools are rarely required and built, so that if Muslim schools are to be admitted to the Voluntary Aided category they will of necessity be already in existence. In effect, this means that in the future a state funded Muslim school will already exist either as a local authority "public" school or as a private establishment. (2001, p. 518)

This has led to a number of campaigns by Muslim organisations to take over schools with a significant concentration of Muslim pupils already in attendance. The most recent effort has culminated in a campaign by the Muslim Association of Britain (MAB) in Scotland to turn a currently Roman Catholic School in Pollockshields (Glasgow), which has an $80 \%$ Muslim pupil intake, into a VA Muslim school (for more examples, see Hashmi, 2002, p. 15). One of the leading proponents of the MAB's campaign is Osama Saeed, who argues that:

We are the second-largest faith grouping in Scotland after Christianity yet we do not have a single Muslim school. Muslim children have to attend supplementary classes on weekends and evenings for their Islamic studies, and Muslim schools would go a major way to redressing this problem. (BBC News, 2003) 
It is not difficult to see this example as evidence of Hewitt's conclusion that Muslims who prefer denominational education are "merely following in the footsteps of Anglicans, Catholics and Jews in seeking to give their children a solid foundation in their own faith before they are let loose in the wider world" (1998, p. 22).

\section{Addressing the Objections}

What the discussion has not yet addressed is whether the desire for Muslim faith schooling can overcome, or at least resist, the key opposing arguments. These range from a principled philosophical opposition to all faith schooling to more focused arguments concerning the nature of Muslim schools and their potential impact on social cohesion in Britain.

\section{The Argument for Autonomies}

One of the most commonly shared views about education is that it should encourage the development of rational and moral autonomy which, in the recent liberal tradition, is characterised by the work of Ronald Dworkin (1985), Amy Guttman (1995), and Joseph Raz (1986) amongst others. This position opposes all forms of faith schooling and strenuously argues that all societies that support autonomy must protect children from "believers who wish to impose on them a non-autonomous conception of the good life" (White, 1990, p. 105). This is a central argument contained within the Humanist Philosophers' Group's (HPG) influential pamphlet, Religious Schools: The Case Against. The HPG begins by charging faith schooling with "indoctrination"-which they characterise as limiting the autonomy of a child by implanting beliefs that neither empirical evidence nor rational argument might change. They then state that:

given the importance of fundamental religious and value commitments to a person's life, such commitments should be entered into only subject to all the normal requirements for valid consent: in particular, competence, full information and voluntariness. Religious schools ... are likely to violate these requirements, partly because of (younger) children's

lack of autonomy and partly because of the nature of such schools' missions. (2001, p. 10)

According to this perspective, young people in religious schools are denied both the option and opportunity to develop competencies in making informed choices, specifically because such schools are predisposed to indoctrinate and proselytise.

There are two very interesting and equally challenging responses to this argument, but due to space constraints, only the one that is most relevant to the general argument will be discussed here..$^{5}$ This response begins by rejecting the a-priori assumption that faith schools are necessarily out to indoctrinate students. For example, the educational philosopher Terrence McLaughlin (1992) outlines multiple launch pads for autonomy which means that whilst "one such starting point for a child is indeed from the basis of experience in a common school" this does not invalidate the alternatives. Instead, he states that:

Another possible and legitimate starting point is from the basis of experience of a particular "world view" or cultural identity; a substantiality of belief, practise or value, as 
in (say) a certain sort of religious school. Such schools, in relation to which parents can exercise legitimate rights of choice, would not seek to entrap their pupils in a particular vision of the good, but try to provide a distinctive starting point from which their search for autonomous agency can proceed. (p. 123)

This offers a more contextual comprehension of how a child's autonomy may develop and is more comfortable with competing conceptions of education amongst different cultural constituencies within a multicultural context that is not hostile to the wishes of religious peoples (Modood, 2005; Spinner-Halev, 2000). More recently, McLaughlin (2003, cited in Best, 2003) has gone further in arguing that it is quite feasible for faith schools to adopt an approach that is relatively neutral—such as those favoured by the AMSS outlined in this article. They argue that since children have to accept many things based on trust in order to progress to autonomy (and possibly reject those things later on), religion should be treated no differently.

Nevertheless, the HPG rightly questions whether indoctrination can ever be avoided, given the difficulty of teaching religion in a way that children can grasp and appreciate in any depth without necessarily accepting beliefs that are difficult, if not impossible, to revise or reject when one has reached the adult age. This is an important criticism which leads to a related debate about the nature of religious knowledge and the conditions under which it can be acquired. Espousing a "Christian perspective" on this matter, Ahdar and Leigh (2005) argue that:

a Christian upbringing need not involve hampering a child's autonomy regarding critical and independent thought. It is just that critical thought and the right use of reason ought to be undertaken from a base of faith first. ... This is autonomy, but not of the Enlightenment kind. It eschews self-direction and self-mastery by the individual's use of unbounded reason. The radically autonomous self cannot live the good life; reason is tainted by the Fall. We are back to a Christian paradox again. It is not a matter of fostering self-esteem but rather self-denial; lose oneself in God to truly find oneself. (p. 233)

Meanwhile, the Muslim perspective eschews the idea of reason being tainted by "The Fall" since in Islam humanity is brought into the world in a state of innocence (fitra), much like Rousseau's concept of tabula rasa (blank sheet). This means that "the concept of 'original sin' as presented in Christian theology is non-existent in the newborn child" (Hussain, 2004, p. 319). This is referred to during the discussion of what a Muslim school's curriculum might look like. In the meantime, we should take from Ahdar and Leigh (2005) the implication that unless children acquire this knowledge at a sufficient depth of understanding, they will not be able to exercise valid consent anyway, so that from the authors' perspective the goal of autonomy is already thwarted. Accordingly, the curriculum and environment of the religious school may be essential to the achievement of a level of understanding that makes informed consent (and thus autonomy) possible.

\section{Civic Assimilation and the Remaking of Muslim Constituencies}

This embedded reading of autonomy can been interpreted as a critique of liberal perfectionist thinking that is often too abstracted from the lived relations and 
real-world contexts in which Muslim schools seek to operate. This is the argument made by Bhikhu Parekh (2000) when he contests the civic assimilationist approach which is based upon a neat separation of public and private spheres. Parekh's argument is that such a view fails to take account of institutions that encompass both:

For example, the school educates future citizens, and has a political dimension. However, since children are not just citizens but also human beings and members of the relevant cultural communities, their parents and cultural community have a vital interest in their education, which makes the school a cultural institution that belongs to private or civic realm. If we stressed the former, we would have to treat the school as a public institution subject to the control of the state and ignore parental choices and cultures; if the latter we would reach the opposite conclusion. (pp. 202-203)

This sort of approach allows the recognition of other intersecting issues affecting the articulation of Muslim identities in Britain (Roy, 2004; Sayyid, 2002). The shape and impact of these issues are subject to debate, but amongst Muslims in Britain, it is evident that there is an attempt to reconfigure what being a Muslim in the West means and part of this process is linked to the issue of schooling. As Johnson and Casteli have argued:

Islam in the West is itself undergoing a change. As part of this change, Muslim schools are engaged in creating an identity for the school, the students and the larger communities associated with them. Most Muslim schools in England are multi-ethnic and draw children from a wide range of social and economic backgrounds. Although mono-faith they portray diverse interpretation of Islam. ... It would not be an exaggeration to describe their task as developing a kind of English Islam which is new and is finding its way and its identity within this new context. (2002, p. 33)

This argument returns us to the third issue motivating the desire for Muslim faith schooling. This is linked to the aspiration for more British-trained theologians who can discuss theological issues with a contemporary resonance to the lived experiences of being a British-Muslim. It is argued that such developments-if publicly endorsed - can provide opportunities for Muslim children to be able to negotiate and reconcile the requirements of their faith with their rights and responsibilities as British citizens (cf. Hussain, 2004).

\section{Muslim Curriculum Objectives and Social Cohesion}

In support of such a project, Ashraf (1990, cited in Ameli, Azram, \& Merali, 2005) has outlined a possible curriculum "Faith" framework. Interestingly, he begins by advocating an autonomy argument that seeks to "eschew any form of indoctrination or compulsion to religion" before distinguishing its two core curriculum aims (pp. 27-28). The first aim is concerned with beliefs and values (cognitive and affective respectively) and includes the following priorities:

[... 1.5 Awareness that God has created different racial groups so that we may know each other and live in harmony, respecting the different and differing customs, values, beliefs and languages of the main cultures of the country. [...] 1.6 Awareness that 
the richness of each community depends on how far it can appreciate and value the achievements of other communities and assimilate them for the benefit of its own existence. [...] 1.8 Development not only of tolerance and concern for the rights and beliefs of others, but a commitment to practical engagement on their behalf on the basis of the awareness that in the eyes of God all have equal rights and are entitled to justice. (Ashraf, 1990, cited in Ameli et al., 2005, pp. 27-28)

Meanwhile, intellectual, emotional, and social skills development are addressed in the second curriculum aim:

2.1 Nurturing and development of the powers of reasoning, reflective and critical thinking, imagining, feeling and communicating amongst and between persons. 2.2 Learning how to maintain, develop and renew (and not merely preserve) the social, economic and political order on the basis of values that are fundamentally derived from great religious traditions and human practice. 2.3 Cultivation and development of the physical well being of pupils.

2.4 Cultivation and development of the abilities of communicative competence both in spoken and written form and through a number of modes including verbal, numerical, mathematical and artistic. 2.5 Awareness of the interplay of performance and change in the social process so that the roots [... and] tentative nature of human condition and interaction are also understood. 2.6 Knowledge of modern science and technology and awareness and a critical understanding of their relationship to socio-cultural ethics [...] 2.7 Mastery of scientific and other skills necessary for work and living in modern society.

It would be beneficial to explore these ideal-type curriculum interests in relation to concerns over social cohesion and fragmentation that frequently arise in debates surrounding Muslim schools (see Meer, 2006). For example, the HPG (2001) argues that it is the lack of "contact" amongst children from different religious backgrounds in separate schools that gives rise to fragmentary social situations. According to them:

If children grow up within a circumscribed culture, if their friends and peers are mostly from the same religion and hence also, very likely from the same ethnic group, and if they rarely meet to learn to live with others from different backgrounds, this is hardly calculated to provide the acceptance and recognition of diversity. We have clear evidence to the contrary in Northern Ireland, where the separation of Catholic schools and Protestant schools has played a significant part in perpetuating the sectarian divide. (p. 35)

Although Catholic schools are used as an illustrative example here (see $\mathrm{McNichol}$ [1988] for a powerful rebuttal to this example), the charge of ethnic exclusivism is not empirically tenable in an analysis of Muslim schools, given the ethnic heterogeneity in the Muslim constituency discussed earlier. As a result, the rest of the objection finds resonance in a commonly held view that any emphasis upon religious particularity results in inter-religious hostility. 
Drawing from empirical work with Jewish faith schools, educationist Geoffrey Short responds to this by arguing that because neutrality, as "the pre-requisites of successful contact be guaranteed", the benefits of mere contact between children "are of limited value, for changes in attitude tend not to generalise [emerge substantively] out of the original contact situation" (2002, p. 570). This is not an advocacy for apartheid as much as a rebuttal to a commonsense assumption. For Short, the relevant consideration is not contact but "anti-racist education which can, in principle, be undertaken as effectively in a faith school as in a non-denominational one" (2002, p. 570). This is evident - if not central - to Ashraf's (1990) curriculum outline which uses Islamic principles to proactively accord universal dignity and worth irrespective of ethnic, religious, or racial difference. Both Ashraf and Short (2002) can be seen as advocates of Gordon Allport's (1954) groundbreaking work on the social psychology of racism. He found that one of the most effective ways to impart knowledge about people different from oneself is through academic teaching in schools rather than the naive laissez-faire approach which assumes that mere exposure and contact with "difference" will resolve prejudices. As one way forward, Shabir Akhtar (1992) has encouraged a type of "delayed assimilation" which states that:

A minority struggling to maintain its identity often welcomes a limited amount of isolation that might enable it to gain the confidence and security it needs in the early days of its establishment. That confidence, once achieved, might later help in its attempts to assimilate on its own terms. (p. 43)

Akhtar is then in agreement with David Konstant, the Roman Catholic Bishop of Leeds, who previously stated that the effect of separate Catholic schools has been integration rather than fragmentation. According to Konstant, "having our own school within the state system helped us to move out of our initial isolation as to become more confident and self assured" (1991, p. 16).

\section{Conclusions}

At a time when Muslim minorities in Britain (and elsewhere) feel subjected to unwarranted scrutiny and suspicion, it is not difficult to find obvious and convincing merit in the arguments of Akhtar (see also Modood, 2007). If Muslim constituencies are granted greater participatory space in the form of provisions for Muslim schooling, it could contribute to the reconciliation of faith commitments and citizenship requirements within a public sphere that has historically included and incorporated other religious minorities before it. This is a key point because it appears increasingly unjust not to afford Muslims with schooling provisions parallel to other faith groupsparticularly because this has historically been an effective method of integrating religious minorities throughout the development of the education system in Britain. Moreover, and having engaged some of the main sociological and philosophical currents at work in the debate surrounding Muslim schooling in Britain, the preceding discussion advocates a recognition of the scope for multiple and/or simultaneously 
valid accounts of autonomy presented in Muslim curriculum objectives and their implications for social cohesion respectively.

\section{Acknowledgements}

This article was first presented to the Islam in West Study Group, Centre for European Studies, Harvard University. I would like to thank the W. E. B. Du Bois Institute for granting my visiting fellowship, and the Economic and Social Research Council for funding my visit. I am grateful to Tariq Modood, Katherine E. Smith, and Simon J. Weaver for their helpful comments on earlier arguments. I accept sole responsibility for the final version.

\section{Notes}

1. None of the bombers had ever attended a Muslim school and it is argued elsewhere that this reaction should be understood as part of a broader tendency, evident in public and media discourse, to conflate and reify radically different issues involving Muslims (see Meer, 2006; Meer \& Noorani, forthcoming).

2. There exists no national survey systematically examining Muslim parents' desires on this issue but according to one source, $50 \%$ of South Asian Muslim parents are in favour, which contrasts with $80 \%$ suggested by the Muslim Educational Trust (see Shaikh \& Kelly, 1989). Interestingly, in their Fourth National Survey of Ethnic Minorities, Modood and Bertroud (1997, p. 323) found that the ethnic composition of a school was more important for White respondents than it was for ethnic minorities, whilst preference for religious composition ranged from the desire of Catholics, who were much more inclined to desire faith-based schools, to Hindus, who were the least inclined for faith-based schooling, with Muslims and Protestants falling somewhere in the middle.

3. The General Certificate of Secondary Education (GCSE) is the standard qualification for students enrolled in compulsory schooling until the age of 16 years.

4. In the National Curriculum each subject has a target that the child should have reached in terms of skills, knowledge and understanding at a particular level for that subject. Key Stage Two refers to the target to be met at age 11 .

5. The second has two parts to it and begins by contesting the assumption that non-religious schools can circumvent issues of indoctrination. Grace (2002), for example, laments the degree of bad faith central to the charge of indoctrination against religious faith schools, specifically because secular schools are not themselves ideologically free zones: "Secularism has its own ideological assumptions about the human person, the ideal society, the ideal system of schooling and the meaning of human existence. While these assumptions may not be formally codified into a curriculum subject designated 'secular education' as an alternative to 'religious education', they characteristically permeate the ethos and culture of state-provided secular schools and form a crucial part of the 'hidden curriculum'" (p. 14). The further objection highlights the contradiction between espousing a radical autonomy argument whilst simultaneously encouraging the inculcation of civic and democratic functionary norms and values (see Ahdar \& Leigh, 2005, p. 231).

\section{References}

Ahdar, R., \& Leigh, I. (2005). Religious freedom in the liberal state. New York: Oxford University Press. 
Akhtar, S. (1992). White Paper on Muslim education in Great Britain. London: The Muslim Institute. Allport, G. W. (1954). The nature of prejudice. Reading, MA: Addison-Wesley.

Ameli, S. R., Azam, A., \& Merali, A. (2005). Secular or Islamic? What schools do British Muslims want for their children? London: Islamic Human Rights Commission.

Ansari, H. (2002). Report on Muslims in Britain. London: Minority Rights Group International.

Anwar, M., \& Bakhsh, Q. (2003). British Muslims and state policies. Warwick, England: Centre for Research in Ethnic Relations, University of Warwick.

Ashraf, S. A. (1990). A suggested common "Faith" framework for the curriculum. In S. R. Ameli, A. Azam \& A. Merali (Eds.), Secular or Islamic? What schools do British Muslims want for their children? (pp. 27-28). London: Islamic Human Rights Commission.

Association of Muslim Social Scientists. (2004). Muslims on education: A position paper. Retrieved January 4, 2005, from http://www.amssuk.com/news.htm

BBC News. (2003, November 23). Muslim school campaign planned. Retrieved June 28, 2005, from http://news.bbc.co.uk/1/hi/scotland/3231012.stm

Bell, D. (2005, January). What does it mean to be a citizen? Guardian Unlimited. Retrieved June 9, 2005, from http://education.guardian.co.uk/faithschools/story/0,1392281, 00.html

Best, R. (2003, February). Faith schools - A review of the debate. Paper presented at a seminar at the Centre for Research in Religious Education and Development, Roehampton, University of Surrey, England.

Burgess, S., \& Wilson, D. (2004). Ethnic mix: How segregated are English schools? Bristol, England: Centre for the Market and Public Organisation.

The Commission on the Future of Multi-Ethnic Britain. (2000). The future of multi-ethnic Britain: The Parekh report. London: Profile Books.

Department for Education and Employment. (2001). Schools building on success. Norwich, England: Stationary Office.

Department of Education and Skills. (2004). Decision makers guidance section 2.4. Retrieved June 3, 2005, from http://www.dfes.gov.uk/schoolorg/guidance-view.cfm?Expand=True\&id=37

Douglass, S. L., \& Shaikh, M. A. (2004). Defining Islamic education: Differentiation and applications. Current Issues in Comparative Education, 7, 5-18.

Dworkin, R. (1985). A matter of principle. Cambridge, MA: Harvard University Press.

Grace, G. (2002). Catholic schools: Missions, markets and morality. London: Falmer Press.

Guttman, A. (1995). Civic education and social diversity. Ethics, 105, 557-579.

Halstead, J. M. (1991). Radical feminism, Islam and the single-sex school debate. Gender and Education, 3, 263-278.

Halstead, J. M. (1992). The case for single-sex schools: A Muslim approach. Cambridge, England: Islamic Academy Conference Papers.

Halstead, J. M. (1997). Muslims and sex education. Fournal of Moral Education, 26, 317-330.

Halstead, J. M. (2005). Education. In T. Choudhury, M. Malik, J. M. Halstead, Z. Bunglawala \& B. Spalek (Eds.), Muslims in the UK: Policies for engaged citizens. London: Open Society Institute.

Haque, M. (2002). Review of the progress of Islamic education. Muslim Education Quarterly, 19, $68-73$.

Hashmi, N. (2002). A Muslim school in Bristol: An overview of the current debate and Muslim school children's views. Bristol, England: CECS, University of Bristol.

Haw, K. F. (1998). Educating Muslim girls: Shifting discourses. Milton Keynes, Buckinghamshire, England: Open University Press.

Hewer, C. (2001). Schools for Muslims. Oxford Review of Education, 27, 515-527.

Hewitt, I. (1998). Final report. Report: The magazine from the Association of Teachers and Lecturers, April, 10-25.

Humanist Philosophers' Group. (2001). Religious schools: The case against. London: British Humanist Association. 
Hussain, A. (2004). Islamic education: Why is there a need for it? Fournal of Beliefs and Values, 25, $317-323$.

Johnson, H., \& Castelli, M. (2002). Beyond Orientalism-how to understand the culture of Muslim schools in England: Some methodological reflections. International fournal of Education and Religion, 3, 33-45.

Keaton, T. D. (1999). "Muslim girls and the Other in France": An examination of identity construction. Social Identities, 5, 47-64.

Kelly, P. (1999). Integration and identity in Muslim schools: Britain. United States and Montreal. Islam and Christian-Muslim Relations, 10, 197-217.

Konstant, D. (1991, January 1). Letters. Times Educational Supplement, p. 16.

McLaughlin, T. H. (1992). The ethics of separate schools. In M. Leicester \& M. Taylor (Eds.), Ethics, ethnicity and education. London: Kegan Paul.

McNichol, U. (1988). Teaching controversial issues in a controversial society. In B. Carrington \& B. Tronya (Eds.), Children and controversial issues. London: Kegan Paul.

Meer, N. (2006). "Get off your knees!" Print media public intellectuals and Muslims in Britain. fournalism Studies, 7, 35-59.

Meer, N., \& Noorani, T. (forthcoming). Rhetoric and perception in the national space: A comparative study in popular understandings of Jewish and Muslim religious minorities in Britain.

Modood, T. (Ed.) (1997). Church, state and religious minorities. London: Policy Studies Institute.

Modood, T. (2005). Multicultural politics: Racism, ethnicity and Muslims in Britain. Edinburgh, Scotland: Edinburgh University Press.

Modood, T. (2007). Multiculturalism, a civic idea. London: Polity Press.

Modood, T., \& Bertroud, R. (1997). The fourth national survey of ethnic minorities in Britain: Diversity and disadvantage. London: Policy Studies Institute.

Mukadam, M. (2005, January). Quoted in: Muslim schools citizenship warning. Retrieved June 10, 2005, from http://news.bbc.co.uk/1/hi/education /4180845.stm

Office for National Statistics. (2005). Office for National Statistics, “Census 2001: Ranking: Ethnicity and religion: Muslim". Retrieved November 3, 2005, from http:/www.statistics.gov.uk/ census2001/profiles/rank/ewmuslim.asp

Office for Standards in Education. (2004). The annual report of Her Majesty's Chief Inspector of Schools 2003/4. Retrieved August 5, 2005, from http://www.ofsted.gov.uk/ publications/annualreport0304/1.921.htm

Office for Standards in Education/Audit Commission. (2002). Inspection of Bradford Local Education Authority. London: OFSTED.

O'Keefe, B. (1986). Faith, culture and the dual system: A comparative study of church and county schools. Lewes, East Sussex, England: Falmer Press.

Parekh, B. (2000). Rethinking multiculturalism: Cultural diversity and political theory. New York: Palgrave.

Parker-Jenkins, M. (1995). Children of Islam. London: Trentham Books.

Parker-Jenkins, M. (2002). Equal access to state funding: The case of Muslim schools in Britain. Race Ethnicity and Education, 3, 273-289.

Phillips, D. (2001). The changing geography of South Asians in Bradford. Retrieved August 1, 2005, from http://www.bradford2020.com/pride/docs/section5.doc

Pye, D., Lee, B., \& Bhabra, S. (2000). Disaffection amongst Muslim pupils: Exclusion and truancy. London: IQRA Trust.

Ratcliffe, P. (1996). "Race" and housing in Bradford: Addressing the needs of the South Asian, African and Caribbean communities. Bradford, West Yorkshire, England: Bradford Housing Forum.

Raz, J. (1986). The morality of freedom. Oxford, England: Clarendon Press.

Roy, O. (2004). Globalised Islam. London: Hurst \& Company.

Sayyid, B. (2002). A fundamental fear: Eurocentricism and the rise of Islamism. London: Zed Books. 
Scott, A., Pearce, D., \& Goldblatt, P. (2001). The size and characteristics of ethnic populations of Great Britain. Population Trends, 105, 6-15.

Shaikh, S., \& Kelly, A. (1989). "To mix or not to mix": Pakistani girls in British Schools. Educational Research, 31, 10-19.

Short, G. (2002). Faith-based schools: A threat to social cohesion? Fournal of Philosophy of Education, $36,559-572$.

Skinner, G. (2002). Religious pluralism and school provision in Britain. Intercultural Education, 13, $171-181$.

Spinner-Halev, J. (2000). Surviving diversity: Religion and democratic citizenship. Baltimore, MD: John Hopkins University Press.

Spivak, G. C. (1988). Can the Subaltern speak? In C. Nelson \& L. Grossberg (Eds.), Marxism and the interpretation of culture. Urbana, IL: University of Illinois Press.

Swann, M. (1985). Education for all: The report of the inquiry into the education of pupils of children from ethnic minority groups. London: Her Majesty's Stationery Office.

Walford, G. (2003). Separate schools for religious minorities in England and the Netherlands: Using a framework for the comparison and evaluation of policy. Research Papers in Education, 18, 281-299.

Werbner, P. (1997). Essentialising essentialism, essentialisng silence: Ambivalence and multiplicity in the constructions of racism and ethnicity. In P. Werbner \& T. Modood (Eds.), Debating cultural hybridity: Multi-cultural identities and the politics of anti-racism. London: Zed Books.

White, J. (1990). Education and the good life. London: Kogan Page. 